\title{
The Influence of Financial Ratio and Corporate Governance on Financial Distress in Indonesian Islamic Banking Period 2013 - 2019
}

\author{
Rizki Syaepullah \\ Universitas Islam Indonesia \\ Rizkisaepull@gmail.com \\ Submitted: 2021-09-30 $\quad$ Revised: 2021-10-08 \\ Published: 2021-12-31 \\ (C)2021 by the authors. Submitted for possible open access publication under the terms and conditions \\ of the Creative Commons Attribution (CC-BY-SA) license (https://creativecommons.org/licenses/by-sa/4.0/) \\ d. DOI : http://dx.doi.org/10.30983/es.v5i2.4857

\begin{abstract}
This study aimed to analyze the factors that affect the financial distress in the Islamic Bank in Indonesia. The scope of this research is focused on the financial ratio variables that is operational cost and operating income, capital adequacy ratio and current ratio, and also focused on the corporate governance variables such as the board of commissioners and the board of directors. The sample was selected by purposive sampling method as many as 14 Islamic bank companies listed on the Indonesian Stock Exchange, which use the data collected within period 2013 - 2019. The data used is secondary data. The analyzing data using the fixed estimation model and classic assumption test. The results of this research showed that the financial ratio variables and corporate governance variables simultaneously affect financial distress conditions. The conclusion is the Board of Directors has no significant positive effect on financial distress conditions, but the Capital Adequacy Ratio and Current Ratio have a significant positive effect on financial distress conditions. While inversely proportional with the Operational Costs and Operational Income and the Board of Commissioners have a significant negative effect on financial distress.
\end{abstract}

Keywords: Financial distress, financial ratio, corporate governance.

\section{Abstrak}

Penelitian ini bertujuan untuk menganalisis pengaruh financial ratio variables yaitu biaya operasional pendapatan operasional, capital adequacy ratio dan current rasio serta difokuskan pada corporate governance yang terdiri dari dewan komisaris dan dewan direksi yang mempengaruhi financial distress pada perbankan syariah. Sampel dipilih dengan purposive sampling method sebanyak 14 perbankan syariah yang terdaftar di Bursa Efek Indonesia dengan jangka waktu data pengambilan data selama 2013 - 2019. Data yang digunakan adalah secondary data. Analysis data menggunakan fixed effect model estimation dan classic assumption test. Hasil penelitian menunjukkan bahwa financial ratio variable dan corporate governance secara simultan berpengaruh terhadap kondisi financial distress. Penelitian ini menyimpulkan bahwa dewan direksi tidak berpengaruh secara signifikan secara positif terhadap kondisi financial distress, tetapi capital adequacy ratio dan current ratio berpengaruh secara signifikan secara positif terhadap kondisi financial distress. Sedangkan biaya operasional pendapatan operasional dan dewan komisaris yang berpengaruh signifikan secara negatif terhadap kondisi financial distress.

Kata Kunci: Financial distress, financial ratio, corporate governance.

\section{Background}

The development of the Indonesian banking sector gave rise to a new system, namely the dual banking system formed within the framework of the Indonesian Banking Architecture. The system provides a more Rizki Syaepullah complete alternative to banking services consisting of the conventional banking system and the Islamic banking system, both of which synergistically and simultaneously fulfill the need for fund mobilization in order to increase the capacity and quality of public financing in
Influence of Financial... 
various economic sectors. The significant difference between conventional and sharia banking systems is in the operational system, in which the sharia banking system applies the principle of profit sharing by prioritizing fairness in the transaction process, ethics in investing, the value of brotherhood and togetherness in production, and avoiding speculation in various transactions 1 .

Based on the results of data analysis, Islamic banking has experienced impressive developments with an average annual asset growth percentage of more than 65\% during the period 2014 - 2018, so that the Islamic banking industry can be expected to have better prospects in the future, including in terms of profitability and in terms of financing effectiveness.

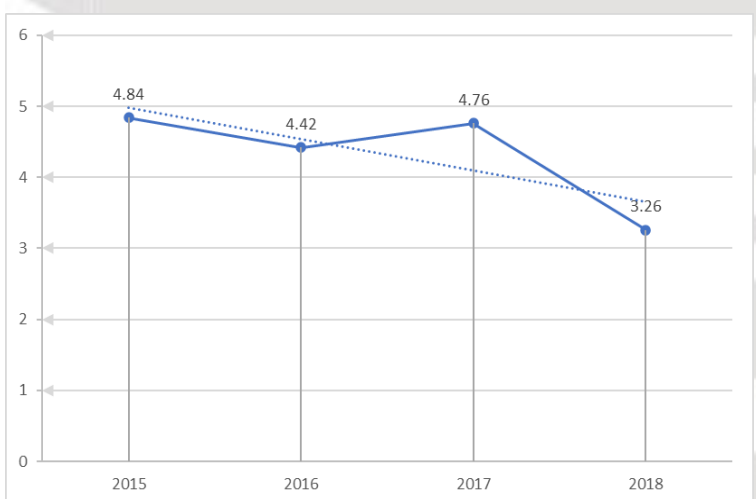

Figure 1 : Ratio of return on assets of Islamic banking

Source: Islamic banking statistics Financial Services Authority

The level of profitability of Islamic banking which is reflected in return on assets, the development of return on assets of Islamic banking during the 2015 - 2017 period was below 1\% except in the 2018 period with the percentage of Islamic banking profitability reaching $1.28 \%$ higher than the minimum standard stipulated by Bank Indonesia regulations. by $1.25 \%$.

1 Sufyati Rahadi, A.P.A., H. Analisis Financial Distress Pada Bank Umum Syariah Di Indonesia. Jurnal Universitas Diponegoro.
Another factor used to assess the soundness of Islamic banking is the ratio of non-performing financing. Non-performing financing aims to measure the level of financing problems faced by Islamic banking. ${ }^{2}$ The higher the ratio of non-performing financing indicates the quality of Islamic banking financing is getting worse.

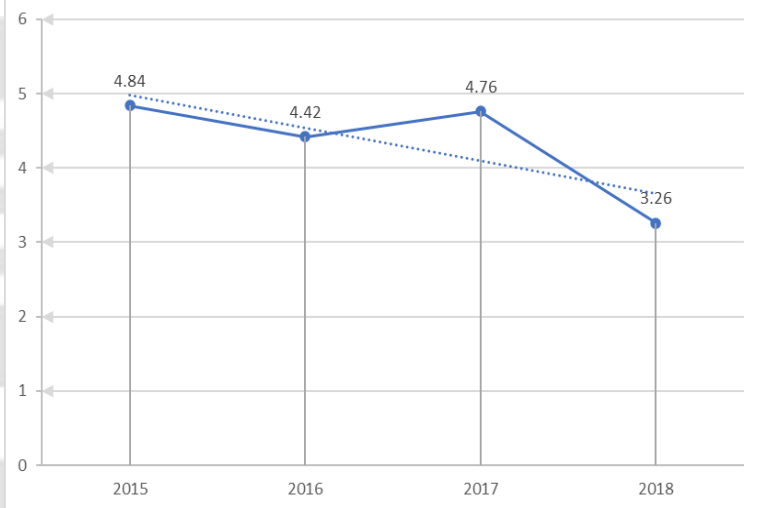

Figure 2 : Ratio of non-performing financing of Islamic banking

Source: Islamic banking statistics Financial Services Authority

The efficiency of Islamic banking financing, which is reflected in non-performing financing, has developed slowly during the 2015 - 2018 period. The percentage of Islamic banking financing effectiveness is smaller than the minimum standard set out in Bank Indonesia regulations, which is $5 \%$.

Profitability and financing efficiency are the main indicators of changes in macroeconomic conditions. In the 2015 2018 period, Islamic banking has not shown positive numbers in profitability and financing efficiency. This shows that the overall development of Islamic banking has not been

2 Heliyani Heliyani, 'Peran Non Performing Financing Terhadap Profitabilitas Bank Pembiayaan Rakyat Syariah Dengan Inflasi Sebagai Variabel Moderasi', EKONOMIKA SYARIAH: Journal of Economic Studies, 4.1 (2020), 111-22; Feri Irawan and Hesi Eka Putri, 'Interaksi Aspek Permodalan, Resiko Pembiayaan, Dan Indikator Makroekonomi Dalam Mempengaruhi Profitabilitas BPRS Di Indonesia Periode 2014-2018', Jurnal Benefita, 5.3 (2020), 401-12. 
able to maintain the company's financial health. If Islamic banking cannot maintain the level of financial soundness, then the potential for Islamic banking to experience bankruptcy conditions begins with the financial distress condition becomes even greater ${ }^{3}$. In anticipating the risk of bankruptcy, regulators and banking management act in bankruptcy prevention by developing an early warning system method to predict potential problems that occur in the company ${ }^{4}$.

Financial distress indicators that lead to the risk of bankruptcy that may be faced by the company can be done by analyzing financial ratios and corporate governance ${ }^{5}$. Thus, there is a possibility that the company's management can interpret various forms of relationships and trends that result in several considerations regarding the potential success of banking companies in the future.

The potential for bankruptcy of a bank can be reviewed and analyzed through financial reports issued by banks. This report is a source of information regarding the financial position of banks, performance and changes in the financial position of banks, which serves as a consideration for making the right decisions ${ }^{6}$. Financial reports that are prepared accurately and well can provide an overview of the situation regarding the company's achievements within a certain time. ${ }^{7}$ Based on

3 B.S. Raharjo, D.P.A., dan Syamsudin, 'Pengaruh Rasio CAR, NPL, LDR, BOPO, Dan NIM Terhadap Kinerja Bank Umum Di Indonesia. Jurnal Universitas Diponegoro', 2011.

${ }^{4}$ B.H. Baltagi, 'Econometric Analysis of Panel Data, 3 Ed. John Wiley \& Son, Inc. Chichester.'

${ }^{5}$ Boitani., 'Development of an Early Warning System for Evaluating the Credit Portfolio's Quality : A Case Study on Romanian Prague. Journal Elsevier'.

6 R. Ningsih, 'Pengaruh Penerapan Profesionalisme Dan Independensi Auditor Terhadap Kualitas Audit. Jurnal Fakultas Ekonomi Dan Bisnis. Universitas Diponegoro.', 2012.

7 Firasari Nukmaningtyas and Saparila Worokinasih, 'Penggunaan Rasio Profitabilitas, Likuiditas, Leverage Dan Arus Kas Untuk Memprediksi Financial Distress (Studi Pada Perusahaan Sektor Aneka Industri Yang Terdaftar Di Bursa Efek Indonesia Rizki Syaepullah this explanation, researchers use financial ratios as indicators used to assess financial performance at the banking level.

The first indicator is an assessment of the quality of the company's management by using the operational cost factor of operating income which is used to measure the level of efficiency of the company in carrying out operational activities. According to the discussion of operational costs, operating income is a comparison between operational financing and operating income, where the lower the level of the company's operational financing will have an impact on the company's operating income which is getting better and the company's management performance is more efficient in using the various resources available in the company ${ }^{8}$. Research conducted related to the company's operational efficiency, there is a positive significant effect of the ratio of operating costs of operating income on the company's financial distress. Likewise with Almilia who stated the results of the study that operational costs of operating income had a significant positive effect on the company's financial distress ${ }^{9}$. It is also not different from the results of the study which found a positive significant effect on operational costs of operating income on the company's financial distress. Different from the three previous studies, the differences in the results found in Indriani's research, stated that the operational

Periode 2013-2016)', Jurnal Administrasi Bisnis, 61.2 (2018), 127-35; Dirvi Surya Abbas, 'Pengaruh Likuiditas, Komisaris Independen, Kepemilikan Institusional Dan Ukuran Perusahaan Terhadap Financial Distress (Pada Perusahaan Sektor Aneka Industri Yang Terdaftar Di Bursa Efek Indonesia Pada Periode 2013-2016)', Jurnal Ilmiah Akuntansi Universitas Pamulang, 7.2 (2019), 119-27.

8 I.N. Tjager, 'Corporate Governance: Tantangan Dan Kesempatan Bagi Komunitas Bisnis Indonesia. Prenhallindo. Jakarta'.

${ }^{9}$ M. Hasibuan, I., Nurhasanah, N., Mahroji, M., dan Cili, 'Financial Ratio Analysis to Predict Financial Distress on Islamic Bank'.
Influence of Financial... 
costs of operating income had no effect on the company's financial distress.

The second indicator is the capital ratio, namely all concrete items contained in the company's balance sheet, the factor of the company's capital adequacy ratio in the ability to accommodate various risks of loss faced by banking companies by using a capital adequacy ratio proxy. ${ }^{10}$ According to the results of research conducted by Sudirman, the capital adequacy ratio is one of the ratios that can function to minimize the risk of losses that may occur in the company, the higher the capital adequacy ratio in a company, the better the ability to bear various risks from each productive credit and productive assets. , the results of Sjahril's (2014) research relating to the capital adequacy ratio, this ratio has a positive but not significant effect on the company's financial distress, while the results of this study ${ }^{11}{ }^{12}$ stated that the capital adequacy ratio has a positive with a significant level of probability on the company's financial distress and the results of research conducted by Nurazi (2005) which states that the capital adequacy ratio has a positive influence with a significant level of probability on the company's financial distress while the results of Pasaribu's research (2015) which contrary to the results of previous studies that the capital adequacy ratio has a negative effect with an insignificant probability level on the company's financial distress.

10 S. Hartianah, D.P., dan Sulasmiyati, 'Pengaruh Aspek Operasional, Corporate Governance, Dan Makroekonomi Terhadap Financial Distress Studi Pada Perusahaan Agrikultur Yang Terdaftar Di Bursa Efek Indonesia Tahun 2011-2015). Jurnal Universitas Brawijaya.'

11 A. Collier, P., dan Gregory, 'Audit Committee Activity and Agency Costs. Econ Papers.'; Michael Firth and Oliver M Rui, 'Voluntary Audit Committee Formation and Agency Costs', International Journal of Accounting, Auditing and Performance Evaluation, 4.2 (2007), 142-60.

12 Collier, P., dan Gregory.
The third indicator that is considered to affect financial distress is the liquidity ratio. Liquidity ratio describes the company's ability to settle short-term obligations (Harahap, 2003). The condition of the company is stated in financial distress when the total current capital is not sufficient for operational obligations which can endanger the sustainability of the company. It is most likely that the company will not face financial distress, if the company has sufficient total current assets or is greater than current debt, it will show a positive signal for creditors, assuming the company can pay the company's expenses that are due on time. Research conducted by Widarjono states that the liquidity ratio as measured by such as: Current Ratio, Liquidity Ratio, Financial Distress, Earning Per Share, and others have no influence on the company's financial distress. However, it is different from research which states that the liquidity ratio as reflected by the current ratio has an effect on the company's financial distress ${ }^{13}$. Meanwhile, it is different from the results of research conducted by Mesak (2019) which states that the liquidity ratio as measured by the current ratio has a negative effect on the company's financial distress. The contribution of the liquidity variable as measured by the current ratio in increasing firm value can be stated that the liquidity variable can provide an overview of the company's ability to meet the company's short-term obligations, where the greater the percentage of the company's current ratio, the company will have a good liquidation level and have an impact on increasing value. on the company. So that the company can provide positive value to investors in investing in the company. Research conducted by Handayani

13 B. Bhagat, S., dan Bolton, 'Corporate Governance and Firm Performance. Corporate Finance. Journal Elsevier.' 
${ }^{14}$. Regarding the effect of several financial ratios on predictions on financial distress conditions in a study of textile and garment companies listed on the Indonesia Stock Exchange for the period 2008 - 2011, the results show that the liquidity ratio as reflected by the current ratio has a significant negative effect on financial distress. The greater the ratio between current assets and current liabilities, the higher the company's ability to cover short-term obligations and vice versa if the lower the comparison results, it will reflect the company's inability to meet short-term obligations.

In addition to the indicators in the financial ratio, corporate governance can also be used as an indicator of a company experiencing financial distress. The success of a company is much influenced by the strategic and managerial characteristics of the company. The application of corporate governance mechanisms in the company will minimize the risk of the company experiencing financial distress (Oet et al., 2013). Based on the provisions of agency theory, the management of the company needs to be monitored and controlled to ensure that the company's management runs the company's operations in accordance with applicable regulations, so that a corporate governance mechanism is needed within the company ${ }^{15}$. The implementation of the corporate governance mechanism serves to minimize company losses caused by agency costs ${ }^{16}$. The better the implementation of the corporate governance mechanism, it can be assumed that the monitoring of the company is carried out properly. This is related to

${ }^{14}$ M.W. Zakarsyi, 'Good Corporate Governance Pada Badan Usaha Manufaktur, Perbankan Dan Jasa Keuangan Lainnya. Alfabeta. Bandung'.

15 W. Hidayat, M.A., dan Meiranto, 'Prediksi Financial Distress Perusahaan Manufaktur Di Indonesia. Jurnal Universitas Diponegoro.'

${ }^{16}$ W.H. Jensen, M.C., dan Meckling, 'Theory of The Firm: Managerial Behavior, Agency Costs and Ownership Structure. University Rochester.'

Rizki Syaepullah increasing company performance and reducing the tendency of financial distress conditions in a company.

Based on the observations of the Financial Services Authority: Otoritas Jasa Keuangan (OJK), Islamic banking in the 2013 2018 period, there were only $25 \%$ of banks that experienced an increase in the value of earnings per share, while the rest had experienced a decline and even showed a minimal negative value in that period. The implementation of corporate governance is considered to be able to affect the financial performance of Islamic banking. Based on the decision of the Deposit Insurance Corporation, there were 6 Islamic banking closures in 2019 due to the implementation of less than optimal corporate governance. Theoretically, the implementation of corporate governance systematics can improve the financial performance of Islamic banking, reduce the risks that may be carried out by the board with decisions that benefit themselves, and can increase investor confidence in investment. This condition can illustrate that Islamic banking is still prone to experiencing financial distress.

The fourth indicator of corporate governance which is considered to have an influence on financial distress is the board of commissioners, as the company's highest internal control mechanism. The board of commissioners has a collective responsibility to carry out supervision and evaluate the performance of the board of directors and company management in the operation of the company. Thus, the board of commissioners does not have direct authority in the company ${ }^{17}$. The experience of the board of

17 dan Rahardja. Sukandar, P.P., 'Pengaruh Ukuran Dewan Direksi Dan Dewan Komisaris Serta Ukuran Perusahaan Terhadap Kinerja Keuangan Perusahaan (Studi Empiris Pada Perusahaan Manufaktur Sektor Consumer Good Yang Terdaftar Di Bursa Efek Indonesia Tahun 2010-2012). Jurnal Universitas Dipon'. 
commissioners plays an important role in determining the quality of monitoring the company's performance.

The fifth indicator of corporate governance which is considered to have an influence on financial distress is the board of directors, as the main person in charge and the highest internal controller in managing the company $^{18}$. Thus the quality of the board of directors has an important role in carrying out the company's management because it is the center of determining the direction of policy and managing the company's resources in the short and long term. ${ }^{19}$.

Various analyzes related to corporate governance on financial distress have been carried out in various settings, including research conducted by Manzaneque (2016) which shows that in a Spanish banking setting with an independent board of directors ownership, the board of directors and the board of commissioners have a role in reducing financial distress, However, different results on the concentration of ownership, institutional - ownership, non-institutional and duality chief executive officer have no effect on financial distress in Spanish banking. Widyasaputri's research (2012) states that corporate governance indicators are one of the important indicators in improving performance and economic efficiency, including a series of relationships between company management, the board of commissioners, the board of directors, shareholders and stakeholders. Ogechukwu's research based on Nigerian banking settings shows that the condition of

${ }^{18}$ Y. Mardiyati, U., dan Murdayanti, 'Pengaruh Ukuran Dewan, Kepemilikan Saham Oleh Direktur, Dan Gender Terhadap Kinerja Keuangan Perbankan. E - Jurnal Manajemen.'

19 Y. Amirulloh, M., dan Isbanah, 'Analisis Model Prediksi Financial Distress Dan Determinan Yang Mempengaruhinya (Studi Pada Perusahaan Sektor Pertambangan Di Bursa Efek Indonesia Tahun 2014 2016). Jurnal Universitas Negeri Surabaya.' banks experiencing financial distress can be identified by the quality of the board of directors and board of commissioners, it is likely that the board of directors and board of commissioners do not have adequate experience in overcoming the complexity of banking company problems. In addition, the chairman of the board of directors, chairman of the board of commissioners and chief executive officer who have share ownership have significant influence both individually and collectively. In addition to the presentation of the results of the analysis, there is some evidence indicating that banks will experience severe pressure from shareholders and stockholders, resulting in a large decrease in the number of customer deposits, although the size of the related banking sector will continue to increase. In Ogechukwu's research, it is emphasized that banking conditions that experience financial distress are caused by poor corporate governance mechanisms. ${ }^{20}$

Based on the problems described in the background of the problem, there is a diversity of research results regarding the analysis of the influence of financial ratios and corporate governance on Islamic banking financial distress.

\section{Hypothesis}

Based on the results of previous studies and can be strengthened by related theories, the hypotheses that can be formed are:

$\mathrm{H}_{1} \quad$ : Operational costs of operating income affect the financial distress of Islamic banking.

$\mathrm{H}_{2}$ : Capital adequacy ratio affects the financial distress of Islamic banking.

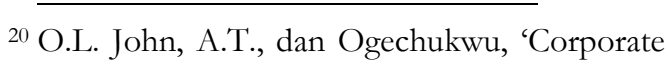
Governance and Financial Distress in the Banking Industry: Nigerian Experience. Journal of Economics and Behavioral Studies.' 
$\mathrm{H}_{3} \quad$ : The current ratio has an effect on the financial distress of Islamic banking.

$\mathrm{H}_{4} \quad$ : The board of commissioners has an effect on the financial distress of Islamic banking.

$\mathrm{H}_{5} \quad$ : The board of directors has an effect on the financial distress of Islamic banking.

\section{Research methodology}

Researchers use a causality research approach because in addition to measuring the strength or questioning the cause and effect problem of the relationship between two or more variables, it will show the direction of the relationship between the independent variable and the dependent variable. The object of research used is the Islamic banking sector with a period of $2013-2019$. The data used in this study is secondary data that is time series and cross section.

\section{Definition of Dependent Variable and Independent Variable}

Variable Financial Distress

This study will use earnings per share to determine the criteria for companies experiencing financial distress. earnings per share is the expected profit per share. earnings per share is widely used to evaluate the operating performance and profitability of the company. A company is considered to have good growth if it has positive earnings per share continuously (Ardiyanto, 2011). This is in accordance with Elloumi's research (2014). Fitriyah (2013) states that companies experiencing financial distress are companies that have negative earnings per share for two consecutive years. Earnings per share is used to analyze risk and compare the company's earnings per share with other companies. The formula for calculating earnings per share is as follows:

\section{Laba Bersih - Deviden Pilihan $\overline{\text { Rata - Rata Saham yang Beredar }}$}

\section{Variable Capital}

The capital adequacy ratio is reflected by the capital adequacy ratio, the capital adequacy ratio is the capital adequacy ratio capable of showing the ability of banking companies to maintain sufficient capital, the ability of company management to classify, identify, measure, supervise, and control various risk symptoms that will arise from the company's operational costs affecting capacity on the capital of banking companies (Dendawijaya, 2009). The formula for calculating the capital adequacy ratio is as follows:

$\frac{\text { Total Modal }}{\text { Total Aktiva Tertimbang Menutur Resiko (ATMR) }} \times 100 \%$

Variable Liquidity

The liquidity variable is reflected by the current ratio which can state how far the comparison between current assets and current liabilities is, the current ratio shows the operational ability to fulfill every current obligation in the company, the higher the current ratio will give an indication that the higher the liquidity capability of the company concerned $^{21}$. The formula for calculating the current ratio is as follows:

\section{$\frac{\text { Total Aktiva Lancar }}{\text { Total Hutang Lancar }} \times 100 \%$}

Variable Efficiency

Efficiency variable is reflected by the ratio of operating costs to operating income reflects the level of efficiency of the company in running operations and managing company resources. The ratio of operating expenses to operating income is the ratio between the operational costs incurred by management in carrying out main activities to the income derived from the company's activities. The

21 S.S. Harahap, 'Teori Akuntansi, 1 Ed. Raja Grafindo Indonesia. Jakarta.'

Influence of Financial... 
formula for calculating operating income operating costs is as follows:

\section{$\frac{\text { Biaya Operasional }}{\text { Pendapatan Operasional }} \times 100 \%$}

\section{Corporate Governance Variable}

The implementation of corporate governance in Islamic banking is needed to avoid the concentration of power in the company's management operations and to create a system of checks and balances. An effective corporate governance system is used to balance the authority for proper distribution of corporate power among shareholders, stakeholders, the board of commissioners, the board of directors, and management. This arrangement is a monitoring mechanism to assess the level of completion of corporate responsibility and corporate accountability through the board of commissioners, board of directors, audit committee, management and auditors to serve and protect the interests of investors (Rezaee, 2002).

Based on research by Ogechukwu (2018), it states that the corporate governance variable can be measured by several indicators such as corporate governance, the board of commissioners and the board of directors. The proportion of the board of commissioners and the board of directors is the ratio scale that will be used in the corporate governance research variable which is measured using the percentage of experience indicators of all members of the board of commissioners and board of directors who come from inside and outside the banking company (Man and Wong, 2013). Meanwhile, in this study, the researchers used an indicator of the average age of the board of commissioners and the board of directors which reflects the experience of the board of commissioners and the board of directors. The board of commissioners and the board of directors are considered more competent in managing the company if they have an age range of 45 to 60 years (FerreroFerrero et al., 2015). The formula for calculating the average age of the board of directors is as follows:

\section{$\frac{\sum U \text { sia Dewan Direksi }}{\sum \text { Usia Dewan Direksi }}$}

The formula for calculating the average age of the board of commissioners is as follows:

\section{$\sum$ Usia Dewan Komisaris $\sum$ Usia Dewan Komisaris}

In this study, researchers will examine the impact after the next period, whether the board of commissioners and the board of directors have the same influence in managing the company.

\section{Results and Discussion}

This research has passed several stages of data selection, such as stationarity test, cointegration test which includes Pedroni test and Kao test. Based on the results of the panel data selection analysis, it was found that the research data was feasible to use.

The data regression panel in this study uses three approaches to estimate the regression model, such as analysis of common effects model estimation, analysis of fixed effects model estimation and analysis of random effects model estimation. Based on the results of the analysis, this study uses a fixed effect model estimation analysis.

Based on the classic assumption test using the normality test, multicollinearity test, autocorrelation test and heteroscedasticity test, it was found that the data and research model are feasible to use because the research data are normal and the research model is free from 
multicollinearity, autocorrelation and heteroscedasticity.

\begin{tabular}{ll}
\hline squared & Watson \\
resid & stat \\
\hline \hline
\end{tabular}

Source: Data processed from Eviews 10.0

Based on the data analysis, it can be seen that the independent variables of the financial ratio which include operating costs of operating income, capital adequacy ratio and

Tabel 4.12 Fixed Effect Model Estimations Cross - Section Seemingly Unrelated Regression

\begin{tabular}{|c|c|c|c|}
\hline Variable & Coefficient & $\begin{array}{c}\mathbf{T}- \\
\text { Statistic }\end{array}$ & Prob \\
\hline $\mathrm{C}$ & $127.721,8$ & 0,779434 & 0,4381 \\
\hline $\begin{array}{l}\text { Operating } \\
\text { Expenses } \\
\text { Operating } \\
\text { Income }\end{array}$ & $-2,663,700$ & $\begin{array}{r}- \\
3,260,858\end{array}$ & 0,0017 \\
\hline $\begin{array}{l}\text { Rasio Capital } \\
\text { Adequacy Ratio }\end{array}$ & $5,628,699$ & 0,862571 & 0,0463 \\
\hline $\begin{array}{l}\text { Rasio Current } \\
\text { Ratio }\end{array}$ & $8,086,438$ & $2,556,184$ & 0,0126 \\
\hline $\begin{array}{l}\text { Board of } \\
\text { Commissioners }\end{array}$ & $-5.138,758$ & $\begin{array}{r}- \\
1,030,423\end{array}$ & 0,0306 \\
\hline $\begin{array}{l}\text { Board of } \\
\text { Commissioners } \\
2\end{array}$ & 45.18535 & $1,072,884$ & 0,0286 \\
\hline $\begin{array}{l}\text { Board of } \\
\text { Directors }\end{array}$ & $1.981,556$ & 0,679006 & 0,6333 \\
\hline $\begin{array}{l}\text { Board of } \\
\text { Directors }{ }^{2} \\
\end{array}$ & $-1,910,060$ & - & 0,6317 \\
\hline
\end{tabular}

\begin{tabular}{lclc}
\hline \hline R-squared & 0,832947 & $\begin{array}{l}\text { Mean } \\
\text { dependent } \\
\text { var }\end{array}$ & 16020,51 \\
\hline $\begin{array}{l}\text { Adjusted } \\
\text { R-squared }\end{array}$ & 0,789556 & $\begin{array}{l}\text { S,D, } \\
\text { dependent } \\
\text { var }\end{array}$ & 37818,94 \\
\hline $\begin{array}{l}\text { S,E, of } \\
\text { regression }\end{array}$ & 18067,67 & $\begin{array}{l}\text { Sum } \\
\text { squared } \\
\text { resid }\end{array}$ & $2,51 \mathrm{E}+10$ \\
\hline F-statistic & $1,919,565$ & $\begin{array}{l}\text { Durbin- } \\
\text { Watson } \\
\text { stat }\end{array}$ & $1,974,431$ \\
\hline $\begin{array}{l}\text { Prob (F- } \\
\text { statistic) }\end{array}$ & 0,000000 & & \\
\hline \hline
\end{tabular}

\begin{tabular}{lccc}
\hline \hline R-squared & 0.698719 & $\begin{array}{l}\text { Mean } \\
\text { dependent } \\
\text { var }\end{array}$ & 10736.62 \\
\hline Sum & $9.90 \mathrm{E}+10$ & Durbin- & 2.105905 \\
\hline \hline
\end{tabular}

Rizki Syaepullah current ratio and corporate governance including the board of directors and the board of commissioners simultaneously affect the earning per share variable significantly, because it is indicated by the probability value of 0.0000 which is much smaller than the significance value of $5 \%$ or 0.05 and the $\mathrm{F}$ - statistic value of 19.19656 which is greater than the F - table value of 2.11 and the determination coefficient in this study of 0.789556 which This means that $78 \%$ of financial distress can be explained by the financial ratio covering operational costs of operating income, capital adequacy ratio and current ratio as well as corporate governance which includes the board of directors and board of commissioners, while the remaining $22 \%$ can be explained by various other variables outside the research model that are not explained in this study. The following is a discussion based on the hypothesis proposed in this study:

Analysis of the effect of operational costs on operating income on the state of Islamic banking financial distress in the period $2013-2019$.

The first hypothesis proposed in this study is that the operating income variable has an effect on financial distress. Based on the results of the regression analysis, it can be seen that the operational income variable has a regression coefficient value of -266.3700 . In addition, the $\mathrm{T}-$ statistic value of -3.260858 which is greater than the $\mathrm{T}$ - table value of 0.67723 and the probability value of 0.0017 which is smaller than the significance value of $5 \%$ or 0.05 , it indicates that partial operational 
cost variable operating income has a significant positive effect on the earning per share variable, so it can be concluded that $\mathrm{H}_{1}$ in this study is accepted.

This analysis shows that an increase in the financing burden of bank companies will result in the level of income obtained by Islamic banking will be smaller. The increase in operational costs in Islamic banking which will be borne by Islamic banking results in a decrease in income derived from financing allocations and higher financing costs will reduce the capital and profits of Islamic banking, the research results are consistent with Khairuddin's research. ${ }^{22}$ (2019), Ufo (2015), (2006) and Mawardi (2004) which state that operating costs of operating income have a significant effect on Islamic banking financial distress, if the condition of the company's operating costs is increasing, it is not matched by the company's operating income, it will result in sharia banking financial distress.

Analysis of the effect of the capital adequacy ratio on the financial distress of Islamic banking in the period $2013-2019$.

The second hypothesis proposed in this study is that the variable capital adequacy ratio affects the financial distress of Islamic banking. Based on the results of regression analysis, it can be seen that the variable capital adequacy ratio has an effect on financial distress with a regression coefficient of 5.628699. In addition, the $\mathrm{T}-$ statistic value is 0.862570 which is greater than the $\mathrm{T}-$ table value of 0.67723 and the probability value of 0.0463 is smaller than the significance value of $5 \%$ or 0.05 . This shows that partially the capital adequacy ratio variable has a significant positive effect on the earning per share

${ }^{22}$ Yacub. Azwir, 'Analisis Pengaruh Kecukupan Modal, Efisiensi, Likuiditas, NPL, Dan PPAP Terhadap ROA Bank (Studi Empiris: Pada Industri Perbankan Yang Listed Di Bursa Efek Jakarta Periode Tahun 2001-2004). Jurnal Universitas Diponegoro.' variable. so it can be concluded that $\mathrm{H}_{2}$ in this study is accepted. The results of this study are in accordance with the results of previous studies conducted by Ufo (2015), Dance (2019) and Chiaramonte (2017).

Analysis of the effect of the current ratio on the financial distress of Islamic banking in the period 2013 - 2019. The third hypothesis proposed in this study is that the current ratio variable has an effect on financial distress. Based on the results of the regression analysis, it can be seen that the current ratio variable has an effect on financial distress with a regression coefficient of 80.86438. In addition, the $\mathrm{T}$ - statistic value is 2.556184 which is greater than the $\mathrm{T}$ - table value of 0.67723 and the probability value of 0.0126 is smaller than the significance value of $5 \%$ or 0.05 .

This shows that partially the current ratio variable has a significant positive effect on the earning per share variable, so it can be concluded that $\mathrm{H}_{3}$ in this study is accepted. The results of this study are in accordance with the results of previous studies conducted by Ufo (2015), Dance (2019) and Chiaramonte (2017).

Analysis of the influence of corporate governance on the financial distress of Islamic banking in the period $2013-2019$.

Corporate governance will encourage an increase in effectiveness and efficiency so that it will have an impact on the level of profitability of Islamic banking which will continue to increase. Likewise, if there is a decline in corporate governance, it will affect the performance of Islamic banking. Increasing the profitability of Islamic banking is a shortterm and long-term goal that must be achieved by Islamic banking. This achievement can be reflected in earnings per share, because investors' assessment of Islamic banking can be observed through up and down movements 
in earnings per share of Islamic banking traded on the Indonesia Stock Exchange. In the implementation process to maximize the performance and profitability of Islamic banking, a conflict of interest will arise between the board of commissioners, the board of directors, stakeholders and shareholders, which is called the agency problem. Not infrequently the board of directors of Islamic banking has other goals and interests that are different from the main objectives of Islamic banking.

The decline in profitability which is reflected in the decrease in the company's earnings per share is due to the performance of the board of directors having no effect on suppressing the potential for financial distress in Islamic banking. This is because the board of directors does not have full authority in making decisions on the company's operational management, is unable to guarantee effectiveness in carrying out the monitoring function of management performance and the absoluteness of the decisions of the board of commissioners in determining the company's operational policies and objectives. This contradicts several theories, such as the board of directors having a very vital role in the company's operational management, the role of determining the direction of policies and strategies for managing the company's resources in the short and long term so that it will improve company performance.

The absolute attitude in the structure and opportunism in the management of the board of commissioners will support the increase in the potential for Islamic banking financial distress, this opinion is based on the results of the study. The increase in the potential for financial distress caused by the proportion of the board of commissioners reflected in the average age will decrease when the average age of the board of commissioners reaches the age of 57 years. This achievement can stimulate the board of commissioners in improving the quality of handling and making sharia banking management policies. In the implementation of sharia banking management, the board of directors has not been able to work effectively to improve the company's performance due to the dominance of the board of commissioners in determining company decisions. There is a tendency that the position of commissioners is very strong so they are reluctant to share authority so they do not share important information related to shareholders to the board of directors such as the validity of financial statements and company management, this statement is reinforced by Effendi's research ${ }^{23}$. Kusumastuti, et al (2007) ${ }^{24}$.

There is an allegation that the company's management often recommends less competent family members to take part in the management ranks so as to rule out the participation of people with more potential than family members, this behavior can result in conditions that are prone to conflicts of personal and company interests. If the incident is not detected and evaluated properly, it will have an impact on decreasing the professionalism of the company's management performance and even decreasing the company's profitability, the researcher's opinion is supported by research by Gudmunson (1999) McConaughy et al (1999). The view of corporate governance is only as a regulatory compliance, companies that have not realized the benefits of undergoing a corporate governance mechanism so that the company's corporate governance mechanism does not work effectively and has no impact on company performance.

${ }^{23}$ M.A. Effendi, 'The Power of Good Corporate Governance: Teori Dan Implentasi. Salemba Empat. Jakarta.'

24 Anna Cahya Mustika and Sri Yani Kusumastuti, 'Determinan Likuiditas Pada Bank Umum Swasta Nasional Non Devisa Di Indonesia Tahun 20032012', Jurnal Ekonomi \& Studi Pembangunan, 16.1 (2015), $53-62$. 
The board of directors cannot carry out its functions and responsibilities optimally, this limitation is due to the policies determined by the majority shareholders, shareholders who are the strong controllers of the company. The majority shareholders have a great ability to determine and influence decisions. The results of this study support Kim's (2010) research ${ }^{25}$, Brown and Caylor, (2004), Barnhart and Rosenstein (1998) ${ }^{26}$, Beiner et al (2004), Gompers et al (2003) Sheikh and Wang (2012), ${ }^{27}$ Anggraini (2013) ${ }^{28}$, and Kor (2003) stated that the board of commissioners has an influence on the potential emphasis on Islamic banking financial distress conditions.

\section{Conclusion}

This study deals with the analysis of the effect of financial ratios as proxied by operational costs of operating income, capital adequacy ratios, current ratios and corporate governance which are proxied by the proportion of the average age of the board of directors and the proportion of the average age of the board of commissioners to the financial distress of Islamic banking. The research sample taken from the study is the annual data of Islamic banking in the period $2013-2019$. The analytical technique used to interpret and analyze the data in this study is the panel data regression generalizes least squares.

25 Kee H Chung, John Elder, and Jang-Chul Kim, 'Corporate Governance and Liquidity', Journal of Financial and Quantitative Analysis, 45.2 (2010), 265-91.

26 Scott W Barnhart and Stuart Rosenstein, 'Board Composition, Managerial Ownership, and Firm Performance: An Empirical Analysis', Financial Review, 33.4 (1998), 1-16.

${ }^{27}$ Nadeem Ahmed Sheikh and Zongjun Wang, 'Effects of Corporate Governance on Capital Structure: Empirical Evidence from Pakistan', Corporate Governance: The International Journal of Business in Society, 2012.

${ }^{28}$ Dina Anggraini, 'Pengaruh Good Corporate Governance Terhadap Nilai Perusahaan Pada Perusahaan Textile, Garment Yang Terdaftar Di Bursa Efek Indonesia (BEI) Periode 2009-2012', Akuntansi, Universitas Maritim Raja Ali Haji Tanjungpinang, 2013.
Financial ratios and corporate governance did not fully have an influence on financial distress. Based on the results of the study, it is known that the operating income operating expense variable has a positive effect on earnings per share of Islamic banking for the period 2013 - 2019. The variable capital adequacy ratio has a positive effect on earnings per share of Islamic banking for the period 2013 - 2019. The variable current ratio has a positive effect on earnings per share. share of Islamic banking for the period 2013 - 2019. The variable of the board of commissioners has a negative effect on the earnings per share of Islamic banking in the period 2013 - 2019. The variable of the board of directors has no effect on the earnings per share of Islamic banking in the period 2013 - 2019.

This shows that financial ratios and corporate governance have a significant influence on Islamic banking financial distress for the period $2013-2019$.

This research has limitations. Assessment of financial ratios and corporate governance as a whole cannot be carried out, this is because corporate governance assessing institutions such as the Indonesian Institute for Corporate Governance have only assessed corporate governance in several Islamic banks and added indicators to the liquidity variable, namely the ratio of liquid assets to short-term funding, and bank size and profitability variables of Islamic banking such as internal determinants and external determinants.

Based on some of the limitations of the research that have been disclosed and expectations for further research, suggestions for further research are given, namely that further research should add proxies for financial ratios and corporate governance.

\section{References}


Abbas, Dirvi Surya, 'Pengaruh Likuiditas, Komisaris Independen, Kepemilikan Institusional Dan Ukuran Perusahaan Terhadap Financial Distress (Pada Perusahaan Sektor Aneka Industri Yang Terdaftar Di Bursa Efek Indonesia Pada Periode 2013-2016)', Jurnal Ilmiah Akuntansi Universitas Pamulang, 7.2 (2019), 119-27

Amirulloh, M., dan Isbanah, Y., 'Analisis Model Prediksi Financial Distress Dan Determinan Yang Mempengaruhinya (Studi Pada Perusahaan Sektor Pertambangan Di Bursa Efek Indonesia Tahun 2014 -2016). Jurnal Universitas Negeri Surabaya.'

Anggraini, Dina, 'Pengaruh Good Corporate Governance Terhadap Nilai Perusahaan Pada Perusahaan Textile, Garment Yang Terdaftar Di Bursa Efek Indonesia (BEI) Periode 2009-2012', Akuntansi, Universitas Maritim Raja Ali Haji Tanjungpinang, 2013

Azwir, Yacub., 'Analisis Pengaruh Kecukupan Modal, Efisiensi, Likuiditas, NPL, Dan PPAP Terhadap ROA Bank (Studi Empiris: Pada Industri Perbankan Yang Listed Di Bursa Efek Jakarta Periode Tahun 2001-2004). Jurnal Universitas Diponegoro.'

Baltagi, B.H., 'Econometric Analysis of Panel Data, 3 Ed. John Wiley \& Son, Inc. Chichester.'

Barnhart, Scott W, and Stuart Rosenstein, 'Board Composition, Managerial Ownership, and Firm Performance: An Empirical Analysis', Financial Review, 33.4 (1998), 1-16

Bhagat, S., dan Bolton, B., 'Corporate Governance and Firm Performance. Corporate Finance. Journal Elsevier.'

Boitani., 'Development of an Early Warning System for Evaluating the Credit Portfolio's Quality : A Case Study on Romanian Prague. Journal Elsevier'

Chung, Kee H, John Elder, and Jang-Chul Kim, 'Corporate Governance and Liquidity', Journal of Financial and Quantitative Analysis, 45.2 (2010), 265-91

Collier, P., dan Gregory, A., 'Audit Committee Activity and Agency Costs. Econ Papers.' Effendi, M.A., 'The Power of Good
Corporate Governance : Teori Dan Implentasi. Salemba Empat. Jakarta.'

Firth, Michael, and Oliver M Rui, 'Voluntary Audit Committee Formation and Agency Costs', International Journal of Accounting, Auditing and Performance Evaluation, 4.2 (2007), 142-60

Harahap, S.S., 'Teori Akuntansi, 1 Ed. Raja Grafindo Indonesia. Jakarta.'

Hartianah, D.P., dan Sulasmiyati, S., 'Pengaruh Aspek Operasional, Corporate Governance, Dan Makroekonomi Terhadap Financial Distress Studi Pada Perusahaan Agrikultur Yang Terdaftar Di Bursa Efek Indonesia Tahun 2011-2015). Jurnal Universitas Brawijaya.'

Hasibuan, I., Nurhasanah, N., Mahroji, M., dan Cili, M., 'Financial Ratio Analysis to Predict Financial Distress on Islamic Bank'

Heliyani, Heliyani, 'Peran Non Performing Financing Terhadap Profitabilitas Bank Pembiayaan Rakyat Syariah Dengan Inflasi Sebagai Variabel Moderasi', EKONOMIKA SYARIAH: Journal of Economic Studies, 4.1 (2020), 111-22

Hidayat, M.A., dan Meiranto, W., 'Prediksi Financial Distress Perusahaan Manufaktur Di Indonesia. Jurnal Universitas Diponegoro.'

Irawan, Feri, and Hesi Eka Putri, 'Interaksi Aspek Permodalan, Resiko Pembiayaan, Dan Indikator Makroekonomi Dalam Mempengaruhi Profitabilitas BPRS Di Indonesia Periode 2014-2018', Jurnal Benefita, 5.3 (2020), 401-12

Jensen, M.C., dan Meckling, W.H., 'Theory of The Firm: Managerial Behavior, Agency Costs and Ownership Structure. University Rochester.'

John, A.T., dan Ogechukwu, O.L., 'Corporate Governance and Financial Distress in the Banking Industry : Nigerian Experience. Journal of Economics and Behavioral Studies.'

Mardiyati, U., dan Murdayanti, Y., 'Pengaruh Ukuran Dewan, Kepemilikan Saham Oleh Direktur, Dan Gender Terhadap Kinerja Keuangan Perbankan. E - Jurnal Manajemen.'

Mustika, Anna Cahya, and Sri Yani 
Kusumastuti, 'Determinan Likuiditas Pada Bank Umum Swasta Nasional Non Devisa Di Indonesia Tahun 2003-2012', Jurnal Ekonomi \& Studi Pembangunan, 16.1 (2015), 53-62

Ningsih, R., 'Pengaruh Penerapan Profesionalisme Dan Independensi Auditor Terhadap Kualitas Audit. Jurnal Fakultas Ekonomi Dan Bisnis. Universitas Diponegoro.', 2012.

Nukmaningtyas, Firasari, and Saparila Worokinasih, 'Penggunaan Rasio Profitabilitas, Likuiditas, Leverage Dan Arus Kas Untuk Memprediksi Financial Distress (Studi Pada Perusahaan Sektor Aneka Industri Yang Terdaftar Di Bursa Efek Indonesia Periode 2013-2016)', Jurnal Administrasi Bisnis, 61.2 (2018), 127-35

Rahadi, A.P.A., dan Sufyati, 'No Title', $H$. Analisis Financial Distress Pada Bank Umum Syariah Di Indonesia. Jurnal Universitas Diponegoro.

Raharjo, D.P.A., dan Syamsudin, B.S., 'Pengaruh Rasio CAR, NPL, LDR, BOPO, Dan NIM Terhadap Kinerja Bank Umum Di Indonesia. Jurnal Universitas Diponegoro', 2011

Sheikh, Nadeem Ahmed, and Zongjun Wang, 'Effects of Corporate Governance on Capital Structure: Empirical Evidence from Pakistan', Corporate Governance: The International Journal of Business in Society, 2012

Sukandar, P.P., dan Rahardja., 'Pengaruh Ukuran Dewan Direksi Dan Dewan Komisaris Serta Ukuran Perusahaan Terhadap Kinerja Keuangan Perusahaan (Studi Empiris Pada Perusahaan Manufaktur Sektor Consumer Good Yang Terdaftar Di Bursa Efek Indonesia Tahun 2010-2012). Jurnal Universitas Dipon'

Tjager, I.N., 'Corporate Governance: Tantangan Dan Kesempatan Bagi Komunitas Bisnis Indonesia. Prenhallindo. Jakarta'

Zakarsyi, M.W., 'Good Corporate Governance Pada Badan Usaha Manufaktur, Perbankan Dan Jasa Keuangan Lainnya.
Alfabeta. Bandung' 